\title{
Arqueologia da Repressão e da Resistência e o DOI-CODI/SP. A materialidade da violência durante a ditadura militar brasileira no século XX
}

\author{
Laura Chan Rissato*, Frederic Mario Caires Pouget.
}

\section{Resumo}

Partindo do conceito de Arqueologia da Repressão e da Resistência, aplicado no contexto dos regimes militares da América Latina, essa pesquisa tem como caso de estudo as instalações do extinto DOI-CODI/SP (Destacamento de Operações de Informações e Centros de Operações de Defesa Interna). O órgão, criado durante ditadura e diretamente ligado às forças armadas, foi desativado em meados da década de 80 e é ainda hoje palco de reivindicações pelo direito à memória. Assim, por meio de documentos do edifício, de relatos de sobreviventes e da participação do Grupo de Trabalho coordenado pelo CONDEPHAAT, esta pesquisa reuniu informações à respeito da materialidade do DOICODI durante os anos de seu funcionamento, a fim de analisar a memória material ditatorial e de sondar métodos eficazes de pesquisa arqueológica neste espaço.

\section{Palavras-chave: \\ Arqueologia da repressão e da resistência, ditadura militar, DOI-CODI/SP}

\section{Introdução}

Com o objetivo de monitorar e perseguir elementos contrários ao governo, diversos órgãos foram criados nas grandes cidades durante o regime militar (1964-1985). Muitos dos edifícios que acomodaram tais órgãos resistiram ao tempo e continuam de pé, e foram apenas desligados ou ressignificados. É o caso do DOI-CODI em São Paulo. Os órgãos foram criados e instalados na cidade em 1970, com objetivos e modos de ação diferentes; enquanto os DOIs eram responsáveis pelas ações de busca e interrogatório de suspeitos, os CODIs eram os órgãos de planejamento, responsáveis pela análise de informações e coordenação do combate aos grupos armados de esquerda. A Arqueologia da repressão e da resistência surge então como possibilidade de estudar e recuperar a memória e a história destes homens, mulheres e crianças que passaram pelo DOI-CODI, uma vez que o estudo da cultura material permite a análise de diversos grupos

historicamente marginalizados.

Assim, este trabalho tem como objetivo não só aprofundar os conhecimentos a respeito da materialidade do espaço de repressão e de resistência do DOI-CODI, por meio da pesquisa das metodologias arqueológicas adequadas a este conjunto de edifícios, mas também entender as relações entre os estudos da arqueologia da repressão e da resistência e a luta contemporânea de sobreviventes da ditadura militar pelo direito à memória, a verdade e à justiça.

\section{Resultados e Discussão}

De início, é evidente o caráter essencial e indissociável da história oral recuperada por meio dos relatos dos sobreviventes e das práticas metodológicas passíveis de serem realizadas no terreno. A reconstituição da materialidade do DOI-CODI deve ter uma abordagem mais completa, se sustentada na memória e na experiência de um grupo amplo de sobreviventes. Isso foi evidenciado por meio de relatos de ex-presos sobreviventes colhidos por essa pesquisa, que tentaram reconstituir em detalhes aquele espaço repressivo e sua materialidade, apontando informações valiosas sobre locais passíveis de descobertas arqueológicas.
Assim, esta pesquisa realizou também uma discussão a respeito dos métodos arqueológicos passíveis de serem empregados àquele espaço, considerando todas as características arquitetônicas e espaciais próprias dos edifícios. Para isso, foram consultados as plantas e outros documentos de detalhamentos técnicos dos edifícios, além do estudo bibliográfico a respeito do tema. Mostraram-se mais adequadas as técnicas da arqueologia da arquitetura, analisando as construções de uma perspectiva teórico-metodológica própria da arqueologia, levando em consideração principalmente as reformas realizadas nos prédios e o estudo da espacialidade original dos anos ditatoriais. Ainda, as práticas arqueológicas de prospecção e aberturas de quadras não aparentaram ser a melhor opção metodológica, dado ao piso do terreno, comprovadamente asfaltado desde o início dos trabalhos do DOI-CODI.

Por fim, é também notável a relevância da contribuição do estudo arqueológico do DOI-CODI para a elaboração de projetos que reivindiquem o direito à memória e a verdade. A participação do Laboratório de Arqueologia Pública (LAP) da Unicamp no "Grupo de Trabalho para Uso dos edifícios que serviram ao DOI-CODI" contribui não apenas com a produção de projetos arqueológicos voltados para o DOI-CODI, mas também auxiliou como foma de ocupação acadêmica de um patrimônio histórico tombado, porém pouco divulgado na cidade de São Paulo.

\section{Conclusões}

A arqueologia da repressão e da resistência é uma poderosa ferramenta para estudar histórias abafadas, como as protagonizadas pelos presos políticos no espaço do DOI-CODI, trazendo não apenas informações relevantes sobre os suportes materiais da repressão e da resistência, mas também auxilia o processo recente de reivindicação à memória.

\section{Agradecimentos}

Agradeço ao meu orientador Frederic Pouget, à responsável pelo Laboratório de Arqueologia Pública Paulo Duarte (Nepam/Unicamp) Aline Carvalho, e ao CNPq. 